\title{
"Hedgerow": A Cooperation between \\ Geography, Didactics of Geography and \\ School Practice to Improve Teacher \\ Training at University
}

\author{
Dr. Stefanie Zecha \\ Catholic University of Eichstätt. Bavaria \\ Germany
}

\begin{abstract}
:
The project "Hedgerow" is a cooperation between the head of the nature conservation project "Altmühlleiten", the assistant professor of the department of didactics of geography of the Catholic University of Eichstätt, and pupils of a primary school. The aim of all partners was to improve the children 's knowledge about hedgerows as well as to promote cooperation between scientific geography and teacher training. In the theoretical part, a selected model that the author uses to describe the term ,cooperation ${ }^{\text {ee }}$ will be presented, the elements of which must be fulfilled to form an effective cooperation. Then, this model is converted to the hedgerow project. The project itself consisted of four steps. Firstly, the participating students of geography didactics are informed about hedgerows in a very interactive way. Hedgerows are a refuge for native wild flora and fauna. They were typical cultural elements of this region but have largely disappeared. After acquiring this information, each university student group prepared one lesson for each school at class level during a didactic lecture at university. With regard to sustainable working and teaching, the students held their prepared lessons in different primary school classes. Finally, the pupils built their own hedgerow in nature. This project can be seen as an illustrative example of cooperation between geography, didactics of geography and school practice.
\end{abstract}

Key words: hedgerow; didactics; application of university research; school education.

Corresponding author: Dr. Stefanie Zecha

E-mail: Stefanie.zecha@ku-eichstaett.de

Educational Research eJournal - ISSN 2254-0385

(C) Faculty of Education. University of Alicante

DOI: 10.5838/erej.2012.11.06 


\section{Introduction}

In this article, an outstanding successful example of practical cooperation between academic instruction in geography and teacher training will be presented. It shows how the obstacle between theoretical teacher training and practice can be overcome. In the theoretical part, the author presents a model of how cooperation between different partners can work. With the help of this model, the cooperation project "hedgerow", which was conducted by the author, will be described. The author explains other aspects that are important for a better understanding of the context, such as teacher training in Germany, especially in Bavaria, the Bavarian school system and the geographical theme "hedgerow". The cooperation described has been performed among the head of the nature project "Altmühlleiten", Dr. Peter Loreth; Dr. Stefanie Zecha from the department of didactics of geography of the Catholic University of Eichstätt-Ingolstadt and her students and pupils of the primary school of Walting, located 10 kilometres away from Eichstätt in Bavaria. The cooperation applied the project in the last week of June 2011. The project "hedgerow" consists of four stages. In the first stage, the students informed themselves about hedgerows at an excursion. Then, the students prepared this information to teach it to primary pupils, held the lessons at a primary school, and finally, the pupils built their own hedgerow together with the university students.

\section{Theoretical part}

The theoretical part exposes different aspects that are in some way important for a better understanding of the cooperation project: the actual situation of investigation in teaching practice during university studies, the cooperation model successfully adopted at this project and its application in the cooperation project "hedgerow". Moreover, the Bavarian Education system, the teacher training system for primary teachers in Bavaria, and the geographical theme "hedgerows", will be treated.

Literature situation about teacher training.

English or German Literature that discusses teaching practice form a profound theoretical view does not really exist (Arnold, 2011). What can be found is a lot of literature on the different concepts that are used in different universities regarding their own respective teacher training concept. In the standard compendiums (as Haberman 1990, "Handbook of research on teacher education"; Good 1998, "International handbook of teachers and teaching, McIntyre 2008 "Handbook of research on teacher education"; Saha 2009, "International handbook of research on teachers and teaching") a genuine article on teacher training at university is missing. Some information can be obtained in special teacher training journals. In the German speaking world, the journal "Journal für Lehrerinnen- und Lehrerbildung" (Journal for Teacher Education) has published two special editions that treat this subject exclusively: "Lernprozesse in Praktika" ("Learning Processes in Internship") (2009), and "Mythos Praxis" (The Myth of Practice) (2011). In the English speaking world, some journals with teacher education as their main subject can also be found. The best known is "Teaching and Teacher Education" (since 1984), "Journal of Teacher Education" (since 1949), "European Journal of Teacher Education" (since 1977), "Studying Teacher Education" (since 2005), "Teachers and Teaching" (since 1995) 
as "Australian Journal of Teacher Education" (since 1975).

As shown in an actual survey about teacher studies in Germany, practical training is integrated in all teacher careers in the different regions in this country. As a base for teacher training, a document of the conference of all state ministers of education (Kultusministerkonferenz: KMK) shall serve us here. These teacher training standards are compulsory for each state (KMK, 2004). These guidelines are the base for the regulations of the different administrative regions and for the study conditions of each university. In these documents, the regulations for the different teaching practice are mentioned: the number of teacher training units, the content of each unit and their temporal period. Moreover, information about the position of the training unit in the degree course scheme/curriculum (bachelor or master) can be obtained there. In most cases, the connection with the rest of the study curriculum is rather loose. Until now, there are almost no theoretically based conceptions about the relations between professional studies on subjects like physics or geography, on studies of subject-oriented didactics, or on educational studies in psychology or pedagogy (Arnold, 2011).

\subsection{Definition of cooperation}

A very important aspect of this article is cooperation. Therefore, the author presents a general model for a successful cooperation first, and then transfers it to the cooperation project "hedgerow".

\subsubsection{Definition and general modelling of cooperation}

In general, cooperation (from Latin cooperare, to work together) can be defined in this way: cooperation is a constructive teamwork between the units of organisation in order to reach the same objectives. In the sociological sense, cooperation has generally a positive connotation and is an antonym to competition and conflict (Reinhold, 2000). As a consequence, people in a cooperative relation do not want any activity that results in a disadvantage to a participant. The participants can reach the aims of the cooperation only if they work together in a constructive way (Kullmann, 2010).

\section{General model of cooperation}

Apart from the established aims, more elements are required to complete an efficient cooperation. These elements can be described in a general model, which has been developed basically from research results of psychological organisation (Spieß, 2004). According to these results, a model of cooperation consists of four elements: communication, coordination, individual competences, and pursuing the same objectives. The special significance of this model is that coordination and communication are neither a different form of cooperation, nor is team-working, nor are any synonyms. These elements are the parts of a good cooperation (Steinheider, 2001).

\section{Communication}

Communication aids the participants in exchanging information. Barnard already emphasized The importance of language for the cooperation process : The importance of language for the cooperation process already was emphasized by Barnhard in his basic work about organisational theory (Barnard, 1938). Later, Schmuck defined communication more exactly, as to which kind of communication is necessary for success: "Clearness in communication, openness to dialogue, talking about conflicts and then finding a solution are the basic requirements for a cooperation culture. The partners will have to accept each other and speak openly (Schmuck, 1994). 


\section{Coordination}

The aspect of coordination is necessary as well. In general, it can be said that coordination organises the relation between cooperation partners and their activities (Steinheider, 2001). In a more detailed way, coordination means the organisation of the activities (structure, process, dates, part targets, regulations, etc.) that have to be followed in order to reach the main objective. Coordination cannot function without communication and individual competences. This can be observed very well whenever a transformation process does not work properly. This may happen e.g. because the partners do not really have the same objectives, or because certain organisation units do not possess the competence of reliability (Kulmmann, 2010).

\section{Individual competences}

The participants need individual competences regarding a certain subject as well as in constructive communication and coordination, to achieve successful cooperation. This aspect refers to the cooperation process especially, but not to the objectives the cooperation is aimed at. Generally, the objectives of a cooperation project depend more on the total power of the whole group and less on the competences of the different units of the group. The sum of the individual experiences every partner has, and the patterns of thinking and behaviour, describes the character of the group (Kulmmann, 2010).

The different aspects of this model can be used for an empiric analysis from different aspects. The process of coordination, communication and objectives can be explained easily to other people. For the aspect of individual competence, this is not possible. The model doesn't contain any information about the extent to which these four aspects should be distinctive and which relation they should have so that the cooperation process can continue for a longer period. Next paragraph 3.1 you can see the transformation of the model to the cooperation project.

\subsection{Some more important aspects}

Some more aspects, which are important for understanding the context of the article, are: the formation of a primary teacher in Germany, the Bavarian school system in which this is conducted, and the significance of the theme of the project in the Bavarian curriculum for geography.

\subsubsection{Formation of primary teachers in Germany}

As most other countries, teachers are educated at university in Germany. Each region in Germany and each university has its own plan about teacher training in university regarding the aspects presented above in 2.1. This article deals with the situation in Bavaria, where the project took place. The formation of primary teachers in Bavaria is conducted at university. Each student chooses a main subject, for example mathematics, history or geography. The students trained to be teachers at elementary schools attend the lectures of the main subject with the other students, such as bachelor students or teacher trainees for secondary schools. Furthermore, the students of primary education attend lectures in three didactic subjects: German, mathematics and one out of the group of arts, sports or musics, as well as special lectures in psychology and pedagogy.

Parallel to their university studies, the students have to undergo six different units of practical training. Some of them take place during the semester, others in the semester vacation. The aim of the practical training units is that the students are qualified in conducting education at school and in designing lessons for school classes at the end of 
their studies. The first practical units of teacher training normally treat general didactic themes. The next practical training units treat special didactic aspects. One example is the following one. In this unit, the students learn to prepare an especially geographical theme at the level of primary education. This practical training consists of the following aspects:

During the semester, the teacher at school is required to perform three lessons and one conference lesson at school for one morning a week

This is accompanied by a didactic lecture, in this case geography at university held by an assistant professor two hours a week during the semester The students perform different tasks in the lecture and hold one lesson in front of the didactic professor of the university at school.

(Bayerisches Staatsministerium für Kultus und Unterricht 2011A)

The units of practical training are marked in some universities in Bavaria. In the University of Eichstätt, it was decided not to evaluate the teaching at school, because the first teaching experiences should be free from pressure to perform. The students should have the possibility to try themselves in teaching. The students get a pass or fail for the whole course.

At the end of the studies, the students have to pass their first governmentrecognised exam. Following a 2-year 'probation' ('Referendariat', a statesponsored period as a trainee teacher, which is mandatory in Germany), the students pass their $2^{\text {nd }}$ State Exam (Bayerisches Staatsministerium für Kultus und Unterricht 2011B). The separation of teacher training into scientific formation at university and a practical period afterwards is controversial. This formation of teacher training in two phases is typically German in comparison with the rest of Europe. For a good formation at university, three aspects must be recognized: scientific knowledge, student perspective and school practice (Arnold 2011).

\subsubsection{Bavarian Education System}

As the project takes place in a Bavarian primary school, we will have to regard the Bavarian school system shortly as well. Each state in Germany is responsible for forming and implementing its own educational policy. Primary school (Grundschule) is for all children from the age of six onwards. It comprises grades 1 to 4 , and the subjects taught are the same for all children. After the 4th grade, the pupils are separated and enter secondary school as 5th graders (at the age of 10). There are three separate types of secondary school: Gymnasium (which leads to higher education), Realschule (which focuses on preparation for clerk jobs) and Hauptschule (which aims toward employment in crafts) (Bayerisches Staatsministerium für Kultus und Unterricht 2011C).

\subsubsection{The geographical theme "hedgerows"}

The main objective of the project was raising awareness about the significance of hedgerows. Hedegerows and hedges are traditional elements of the cultural landscape of the region of Eichstätt. They also exist in Ireland, for example, in the north of Spain, where they have the name 'murales'. They developed because of the interaction between the natural conditions of the region and the agricultural use of the area. The geological underground of the Franconian Jura region around Eichstätt consists of limestone karst. Not far away from Eichstätt, the famous lithographic limestone quarries are situated where the Archaeopteryx was found. In many areas of the region, the depth of the soils is very low. The 
consequence is that when ploughing fields, the farmers pull out stones again and again and move the stones to the surface. To cultivate the fields, they have to remove these stones. In former times, they collected these stones by hand and accumulated them to walls on the borders of the field. In time, a living space for plants and animals developed on the stone walls. Thus, the simple borderline developed in time into a "living fence". Because of the gradual consolidation of farmland in the latter part of the $20^{\text {th }}$ century, most of these hedgerows disappeared. The still existing hedgerows are very important living areas for rare plants and animals. They are also important for the regional landscape of this area. The conservation of the existing hedgerows and hedges is a very important mission of nature protection (Wegener 1998; Blab 1993).

After the theoretical presentation follows now the description of the project.

\section{The project hedgerow}

\subsection{The transfer of the cooperation model to the project}

The plausibility and practicability of this general model of cooperation will now be exemplified on the cooperation project "hedgerows", the main theme of this article.

\section{Common objectives}

The main objective of the project was to improve the relation between university studies and teaching practice, and to inform pupils about the significance of hedgerows as elements in the cultural heritage area of Eichstätt. The head of the cooperating nature project "Altmühlleiten" intended to propagate knowledge about hedgerows with the help of the pupils. They should tell their parents about the significance of hedgerows and thus distribute the knowledge. The associate professor of didactics intended that the students learn education with the aid of an actual geographical theme in their environment, and how to prepare such a topic for primary pupils. We should highlight that students hold the prepared lessons at school in a real project. The head of the primary school intended that her pupils get informed about hedgerows before she started to build them with her pupils near the school. Without this knowledge, this practical work would not have been very sustainable.

\section{Coordination}

Coordination is an integral aspect of cooperation. A successful cooperation must be planed. There were different meetings between the cooperation partners. The first took place at the beginning of April, when the head of the primary school, the director of the Altmühlleiten project and the associate professor met. In this conference, they set up a timetable for the project. At the end of this session, each partner knew what he had to do in a certain period of time. Later on, the head of the primary school went to one didactic lesson, in order to present herself and the situation of the school. The students presented the content of the prepared lessons to her, so that she knew what would happen in the different classes during that day.

\section{Communication}

As the project only consisted of three partners, communication was not very difficult to handle. Apart from the meetings, the partners exchanged information via internet.

\section{Individual competences}

This cooperation was voluntary, so the partners worked very openly together. They benefited from the different aspects of knowledge of each organisational unit. The head of the Altmühlleiten project was responsible for the geographical knowledge about 
hedgerows and their special meaning for the cultural area of Eichstätt, The associate professor of didactics was responsible for the presentation of the theme from the perspective of geography didactics, so that the students had the possibility to prepare elaborated lessons. The head of the primary school was responsible for the logistic organisation of the project day. Moreover, communication and coordination competences existed, as the partners already knew each other from different other projects.

Evidently, all aspects of good cooperation were fulfilled. The project was characterised by different competences, in which each member allowed the others to share, with an open communication based on all participants making great efforts in playing a part in the project, a wellplanned coordination adhered to, and a common objective towards which everybody strove to benefit from.

\subsection{The execution of the project}

The project titled "Hedgerow" aimed at connecting teacher training at university with school practice and geographical education. The project "Hedgerow" consisted of four steps (figure 1).

Figure 1: structure of the cooperation project Hedgerow

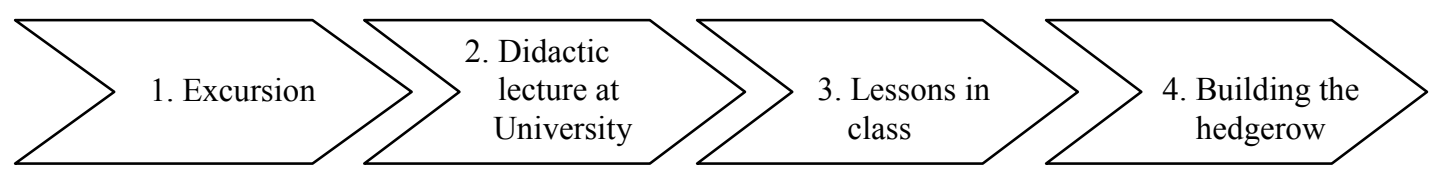

First step: Preparation of the subject "hedgerow" from the scientific viewpoint

The introduction was carried out as a half day excursion to different existing hedgerows near Eichstätt. Dr. Peter Loreth, the head of the nature project "Altmühlleiten", informed the students about the scientific aspects of hedgerows in this cultural area. He used this method instead of a power point presentation in class, because it is more interactive and motivating for the students to get involved in the theme. The students had the possibility to look at a hedgerow, to touch it, to ask questions, or take photos of special aspects of the hedgerow, which they later used in their lessons. In comparison to other geographical subjects, which are often presented in school lessons only, the students had real contact with the subject. For this reason, the students acquired geographical professional competence in a very interactive way.
Second step: Preparation of the subject "hedgerow" from the didactic point of view

After this introduction and with the help scientific literature, the students prepared this geographical content on the level of primary school pupils in the didactic lecture during the semester. The pupils at the primary school knew very little about hedgerows before the project day. At end of the lessons, the primary pupils should have understood:

- the construction of a hedgerow.

- the tradition and historical context of hedgerows.

- a hedgerow as living space for - different plants and animals.

- reasons to protect hedgerows, especially in their region.

- develop a positive feeling towards hedgerows, as part of the cultural heritage.

The didactic lecture took place during the summer semester (20011) two hours a week. In each lecture, the students got 
a task to prepare for the next lecture. These tasks were always related to their practical teacher training. Later, the results were discussed in the lecture. In the second part of the lecture, different didactic aspects were treated to improve their capability to analyse the special situation in lessons, identify teacher conditions, create a stimulating teaching atmosphere, plan lessons, create teacher activity, encourage students for learning, diagnose learning progress and evaluate lessons. These general aspects were discussed with the help of the theme "hedgerow". At the end of the course, two students had prepared one lesson for each class level, one of which is presented in detail in this article as an example. This was a learning circle, which the students prepared for the pupils of the $4^{\text {th }}$ class. On the basis of four stations, the pupils got to know the significance of hedgerows in this region. Each station used a different didactic method; moreover, each station treated a different aspect of the theme. The lesson started with a story about an animal that had lived for a long time in a hedgerow and now had to move out, because somebody wanted to destroy the hedgerow. The students of didactics had written the story themselves. Then, the students divided the pupils into four groups and explained each station to the pupils. The first station treated the theme "how hedgerows have developed". The text was divided in strips and the pupils had to put the strips in the right order. With the help of a cloze test, the pupils could write down the results. The second station treated the aspect of the value of hedgerows for animals and plants. The teacher students had produced a short audio drama. The pupils listened to the audio drama and had to answer questions on a working sheet. The third station dealt with the animals and plants that live in the hedgerow. The pupils had to read the text, and then they had to tick the right answer on a working sheet. The fourth station dealt with the theme "why hedgerows disappeared" with the help of a domino the pupils had brought. For those who were faster, the students had developed a crossword. At the end of the lessons, the pupils got together and talked about hedgerows.

Third step: the presentation of the lessons at school

At the end of June, the whole student group went to the primary school of Walting for one morning. There, the students held their lessons in the different classes. Two students were responsible for each class. In the reflection of the session, the students emphasised how important it was for them to work with a concrete example.

Fourth step: construction of the hedgerow

Two days later, the pupils of the primary school built their own hedgerow near the school.

This cooperation was advantageous to all partners. The school profited from the free and well prepared lessons of the students. The students learned to prepare a geographical theme at the level of primary pupils and to gain more school experience. One student said:"We could use our own working material and test it. That was very important for me. This was a stimulus to make the material very elaborated." The assistant professor had the possibility to introduce interesting geographic didactic aspects, with the help of an interesting geographical theme situated in the environment of the students and the pupils. In this way, new methods can enter the school. An intact cooperation always functions well when all partners benefit from it.

\section{Conclusion}

The aim of this article was to demonstrate how a good cooperation between university studies and teacher training can 
help to improve the teaching competences of the students.

Further discussion could be prompted by the question "how it is possible to improve these connections between university teaching and school practice". As this was only a description of the project, it would also be interesting to evaluate such a project, in order to have exact data about the value of these various kinds of cooperation for the different partners.

Moreover, the project won a prize in the contest "Nice moments in the area of the Altmühl valley" at the Oberbayerische Kulturtage festival in Eichstätt.

Acknowledgements: Dr. Peter Loreth, Claudia Schorer-Dreml (the director of the primary school), the students of the didactic course in the summer semester 2011.

\section{References}

Arnold, K. (2011). Empowerment durch Schulpraktika. Bad Heilbrunn 2011. [Abstract] [Back to text]

Barnard, C.I. (1938), The Functions of the Executive, Cambridge, MA: Harvard University Press. [Back to text]

Blab, J. (1993). Grundlagen des Biotopschutzes für Tiere, in: Bundesforschungsanstalt für Naturschutz und Landschaftspflege (Ed.); Schriftenreihe für Landschaftspflege und Naturschutz, Heft 24, Bonn-Bad Godesberg.

[Abstract] [Back to text]

Bayerisches Staatsministerium für Kultus und Unterricht (2011A). Organisation der Praktika für die Lehrämter an öffentlichen
Schulen.

http://www.km.bayern.de/lehrer/1

ehrerausbildung.html $(15$.

September 2011) 9-18.

[Full text] [Back to text]

Bayerisches Staatsministerium für Kultus und Unterricht (2011B), Vorbereitungsdienst Lehramt Grundschule.

http://www.km.bayern.de/lehrer/l ehrerausbildung/grundschule/refer endariat.html (15. September 2011). [Full text] [back to text]

Bayerisches Staatsministerium für Kultus und Unterricht (2011C), www.km.bayern.de $/ \mathrm{km} / \mathrm{schule} / \mathrm{sc}$ hularten/ (15. September 2011). [Full text] [Back to text]

Good, T.L. (eds) (1998), International Handbook of Teachers and Teaching. New York.

[Abstract] [Back to text]

Haberman, (Eds), (1990), Handbook of Research on Teacher Education. New York. [Back to text]

Journal Für Lehrerinnen- und Lehrerbildung. (2009). Lernprozesse in Praktika. [Abstract] [Back to text]

Journal Für Lehrerinnen- und Lehrerbildung. (2011). Mythos Praxis. [Abstract] [Back to text]

KMK - Kultusministerkonferenz (2004), Standards für die Lehrerbildung. http://www.kmk.org/fileadmin/ve roeffentlichungen beschluesse $/ \mathrm{O}$ hne Datum/00 00 00Lehrerbildung-in-Deutschland.pdf (2.1.2012). [Full text] [Back to text]

Kullmann, H. (2010). Lehrerkooperation. Ausprägung und Wirkungen am Beispiel des naturwissenschaftlichen 
Unterrichts an Gymnasien.

Berlin.

[Full text] [Back to text]

Mc Intyre, D.J. (2008). Handbook of Research on Teacher Education. New York. [Back to text]

Reinhold, G. (2000). Soziologie-Lexikon. München.

[Abstract] [Back to text]

Saha, L. (2009). International Handbook of Research on Teachers and Teaching. London.

[Full text] [Back to text]

Schmuck , R.A. (1994). The Handbook of Organization Development in Schools and Colleges. Illinois. [Abstract] [Back to text]
Spieß, E. (2004). Kooperation und Konflikt. In Schuler, H. (eds.), Organisationspsychologie Gruppe und Organisation, Göttingen, 193247. [Abstract] [Back to text]

Steinheider, B. (2001). Kooperation in interdisziplinären Teams in Forschung, Produktentwicklung und Kunst. In Oberquelle, $\mathrm{H}$. (Eds.), Mensch \& Computer. Stuttgart 37-46.

[Full text] [Back to text]

Wegener, U. (Ed.) (1998). Naturschutz in der Kulturlandschaft, Schutz und Pflege von Lebensräumen. Ulm. [Abstract] [Back to text] 